\title{
KEBEBASAN WANITA DALAM MENENTUKAN CALON SUAMI: PERPSEKTIF HUKUM POSITIF DAN FIQH
}

\author{
Rayno Dwi Adityo \\ Hukum Keluarga Islam Fakultas Syariah UIN Maulana Malik Ibrahim
}

\begin{abstract}
Abstrak:
Perempuan kerap kali tidak memiliki opsi dalam memilih calon suaminya, sehingga berujung pada perkawinan paksa, ini merupakan bagian dari sebuah fenomena sosial yang sering terjadi, umumnya wanita menjadi pihak yang dirugikan. Peristiwa semacam ini kerap terjadi di lingkungan terdekat, kemudian seakan menjelma menjadi tradisi. Tujuan penelitian secara khusus memberikan gambaran komprehensif bagaimana wanita memiliki hak untuk memilih calon suaminya tanpa paksaan. Metodologi penelitian yuridis normatif dengan pendekatan kualitatif. Hasilnya pertama, adalah baik hukum positif dan fikih memberikan ruang untuk wanita dalam memilih pasangan hidup terlepas dari paksaan pihak manapun. Kedua, terjadinya peristiwa kawin paksa dalam kacamata ilmu sosial sangat erat dengan faktor budaya, pendidikan dan pemahaman agama yang sempit. Kesimpulannya kawin paksa tidak sejalan dengan hukum positif dan begitu pula dalam fiqh.
\end{abstract}

Kata Kunci : kawin paksa, fenomena sosial, hak memilih.

\section{Abstract:}

Forced mariages is social phenomena, because often occurs, majority who are often victim is women and it often happen inside or outside the family. Forced marriages seeming to be an tradition, the patterns is varied. Someone is forced to marriage, because their paradigm is the solution of resolve the problem inside their family. Specific purpose is to give a holistical description that the women have a right to choosed their own husband without compulsion. The Metodology used legal normative and kualitatif approach. The result is, first, even though, the forced marriages is contradictory with the positiv law dan so the fiqh perspective, and the second, from social approach that forced mariages is have relation with culture, education, and a narrow interpretation of text religion sources. The truth is that a women right to choosed a man who will be her husband.

Keywords : forced marriages, social phenomena, right to choosed.

\section{PENDAHULUAN}

Kebiasaan tertentu yang dianggap telah mapan dan melekat sebagai sebuah tradisi dokrin adat istiadat terkadang tidak mungkin lagi dikritisi, maka sering sulit untuk dirubah. Sedangkan sebagai sebuah kebiasaan tertentu tidak selamanya baik bagi kemajuan peradaban dalam sudut pandang kehidupan komunal maupun kehidupan bernegara. Memang, budaya serta tradisi merupakan bagian identitas bangsa, tetapi disisi lain jika tak dapat bersinergis dengan cara pandang negara yang terjadi adalah muncul pertentangan 
dan produk regulasi yang dihasilkan negara menjadi tidak efektif.

Dari sekian banyak hal yang terbentur dengan tata aturan hukum, salah satunya adalah tradisi kawin paksa. Kebiasaan memaksakan sebuah perwakinan telah menutup ruang seseorang untuk dapat memilih pasangan pendamping hidupnya, terlebih yang menjadi korban rata-rata pihak wanita. Peristiwa kawin paksa hampir terjadi merata di belahan dunia manapun, seperti di Ethiopia. (liputan6.com, 2017). Kondisi serupa ada di Indonesia, hampir di setiap wilayah secara merata pernah terjadi, misal di Kabupaten Bekasi. (harnas.co, 2018) dan Tasikmalaya Jawa Barat. (detik.com, 2019).

Perkawinan yang didasari atas paksaan bukan tidak mungkin akan menimbulkan masalah sosial baru, seperti suburnya keluarga yang jauh dari kondisi sejahtera dan menjadi penyebab perceraian. (Agus Mahfudin \& Siti Musyawaroh, 2019).

Idealnya dalam proses perkawinan dapat mempertimbangan seluruh aspek termasuk psikis dan finansial. Aspek finansial bukan diterjemahkan kaya raya melainkan tercukupi kebutuhan dasar lahiriyah minimal pangan serta sandang. Kesiapan finansial menjadi salah satu alasan logis dalam membina rumah tangga.
Aspek psikis dengan memperhatikan kesiapan mental, siapkah menikah di usia dini dengan segala konsekuensinya seperti jika terjadi perundungan dimasyarakat karena usia perkawinan yang masih sangat muda (usia anak-anak). Pertimbangan dari semua aspek mesti disikapi secara proporsional. Selain karena faktor pengaruh tradisi pada masyarakat tertentu, terdapat faktor lain, seperti halnya pemahaman agama yang sempit, doktrin yang digunakan tidak jarang mengesampingkan atau bahkan seakan meniadakan dalil-dalil lainnya sebagai sebuah alternatif pilihan, misalkan bagaimana agama Islam mengatur dalam kitab suci Al-Qur'an seperti surat As-Shad ayat 26, Al-An'am ayat 119, Al-Qashah ayat 50 dan Al-Maidah ayat 77, kesemuanya tentang peringatan seseorang agar dapat mengelola hawa nafsu nya. Jika yang dijadikan dasar adalah menghindari pergaulan bebas, maka peran orang tua pun patut menjadi pertimbangan, dengan berperan aktif melakukan pengawasan yang baik terhadap pergaulan anak.

Saat proses penulisan ini, di tingkat pusat, sedang digodok sebuah payung hukum untuk melindungi perempuan, berupa rancangan Undang-undang Pencegahan Kekerasan Seksual (RUU PKS) Terhadap Perempuan dimana salah satu poin penting gagasan tersebut adalah 
adanya keterangan pasal $11 \mathrm{Bab} \mathrm{V}$ ayat 2 huruf (f), bahwa tindakan melangsungkan perkawinan dengan paksa merupakan kategori pidana. Peristiwa pidana itu dapat terjadi karena adanya relasi kuasa, pada pasal 11 ayat 3, relasi kuasa dimaksud contonya terjadi di lingkungan keluarga, rumah tangga, relasi kerja publik, dan situasi khusus lainnya. Tidak jarang bentuk-bentuk pemaksaan tersebut berupa intimidasi, kekerasan fisik maupun dalam bentuk kekerasan verbal.

RUU PKS memang memunculkan pandangan pro dan kontra di masyarakat, tetapi bagaimanapun kemunculan rancangan peraturan tersebut perlu dipahami sebagai sebuah itikad baik negara dalam melindungi hak-hak perempuan. Ada adagium populer, jika ingin membunuh hama di suatu ladang maka temukan hamanya dan basmi, bukan sebaliknya membakar hangus ladang tersebut. Jika terdapat pasal-pasal yang secara prinsipil dianggap bertentangan dengan aturan agama mnapun maka silahkan ditolak, tetapi jika pasal tersebut sejalan maka sejatinya harus didukung. Berdasarkan latar belakang tersebut, penulis merasa tertarik jika tema ini diangkat kembali kepermukaan dengan menitikberatkan pada pendekatan kajiankajian hukum dan sosial. Dalam penulisan kali ini peneliti beri judul, "Kebebasan
Wanita dalam Menentukan Calon Suami: Perspektif Hukum Positif dan Fiqh."

Penulis merumuskan ke dalam dua permasalahan yaitu: Apakah hukum positif serta fiqh mengakomodir hak wanita dalam menentukan calon suaminya? dan Bagaimanakah kawin paksa dilihat dari pendekatan ilmu sosial?

Penelitian ini setidaknya memiliki dua tujuan pokok yaitu, pertama, secara khusus adalah memberikan pemahaman bahwa perempuan memiliki hak dasar yang melekat untuk memilih calon pendamping hidupnya tanpa paksaan pihak manapun. Kedua, secara umum sebagai sumbangsih kecil untuk menambah informasi masyarakat akademis.

Metodologi penelitian ini bersifat konseptual ilmiah dengan pola lintas ilmu dan kajian/multidisipliner. (S. Soekanto, 2006).

Metode pendekatan yang digunakan adalah normatif hukum. (S. Soekanto \& S. Mamudji, 2007), dengan cara pandang kwalitatif. (J. W. Creswell, 2014).

Dari segi jenis penelitian yaitu penelitian kepustakaan (library reseacrh). Sumber data terdiri dari sumber primer, sumber sekunder dan tersier. Primer meliputi Undang-undang, Fiqh, dan peraturan lainnya, sumber sekunder yakni, buku-buku hukum, sosial, jurnal ilmiah dan buku-buku hukum Islam serta sumber 
data tersier yaitu internet dan kamus bahasa asing juga keistilahan. Analisa data dengan metode deskriptif analitis, dengan mengurai inti masalah secara umum.

Kajian pustaka, oleh penulis pertama-tama dengan mencoba menelusuri penelitian sebelumnya, ternyata cukup banyak yang membahas di seputar isu perkawinan terlebih pada isu kwain paksa Beberapa dapat penulis jabarkan daintaranya; skripsi Muhammad Ihsan Armia, mahasiswa syariah UIN Maliki malang dengan judul, "Kawin Paksa Dalam Perspektif Fikih Islam dan Gender." Titik tolak penelitiannya selain membahas kawin paksa dari sudut pandang fiqh Islam klasik, ia juga melakukan pendekatan dengan isu gender. (etheses.uin-malang.c.id, 2019).

Artikel Arif Kurniawan dalam jurnal Al-Ahkam UIN Sunan Kalijaga yang berjudul, "Kawin Paksa Dalam Pandangan Kiai Krapayak," (Arif Kurniawan, 2016), inti pembahasannya bagaimana perspektif kiai Krapayk dalam melihat fenomena kawin paksa.

Terdapat objek pembahasan yang berbeda. Perbedaan dari sisi penulis serta pada peneliti pertama dan kedua, bahwa penulis menelusuri tentang kebebasan wanita memilih calon suami melalui sudut pandang hukum positif dan dipadukan dengan ilmu-ilmu sosial kritis termasuk di dalamnya ilmu sistem sosial budaya. Adapun kutipan ilmu fiqh hanya dari sisi pendapat ulama kontemporer. Sehingga menjadi jelas tidak melebar ke kemanamana. Pembeda lainnya, tulisan ini mengungkapkan kebolehan seorang wanita dalam menentukan pilihan calon suaminya.

Sebelum kita analisa, akan lebih baik pula untuk mengemukakan teori-teori dasar yang memiliki relvansi untuk mengurai kajian ini, pertama, teori singkat fenomena sosial dan sistem sosial budaya. Peristiwa yang terjadi di seputar kita merupakan bagian dari kehidupan sosial, peristiwa-persitiwa tersebut tidak sedikit terjadi berulang-ulang, kesemuanya itu menjadi bagian dari fenomena sosial/gejala sosial. Jika suatu peristiwa hanya terjadi sekali maka ia hanya didudukkan sebagai sebuah kasus saja bukan fenomena sosial (M. Jacky, 2015). Aktifitas menelitinya disebut analisa fenomenologis sebagai bentuk reaksi terhadap paradigma positifistik. (I.B. Irawan, 2014). Paradigma positifistik sangat bebas nilai, bersifat linier, objektif dan netral, dalam bahasa yang mudah dipahami yaitu paradigma ini terlampau rigid dan kaku. (M. Jacky, 2015).

Budaya sebagai suatu bentuk sistem sosial, secara definitif, Talcott Parsons 
menjelaskan bahwa sistem sosial merupakan proses interaksi yang terjadi di antara pelaku sosial (aktor) dan merupakan struktur sistem sosial, struktur relasi terjadi antara pera pelaku yang terlibat pada proses interaksi sebagai suatu jaringan relasi. (Jacobus Ranjabar, 2013). Turunan dari budaya adalah tradisi, yaitu kebiasaan turun menurun. (M. Dahlan Al-Barry, 1994).

Terdapat beberapa faktor penentuan pengaruh suatu nilai budaya, antara lain: nilai bidang agama, nilai bidang pendidikan, nilai bidang komunikasi sosial, nilai bidang ilmu pengetahuan, nilai bidang kesehatan, nilai bidang kependudukan, nilai perumahan dan pemukiman, nilai kesejahteraan sosial, nilai generasi muda, nilai peranan wanita dalam pembangunan bangsa. (J. Ranjabar, 2013). Pengaruh nilai budaya juga meliputi ada motif ekonomi maka unsur kepalsuan melekat padanya, karena selalu beriringan dengan motif iming-iming seperti pekerjaan pribadi, liburan, penuruan berat badan, hiburan, kepuasaan seksual dan motil lainnya, setidaknya itu yang dikatakan Marx. (B. Agger, 2017). Keberagaman budaya serta tradisi masyarakat yang kompleks tidak tertutup kemungkinan terdapat konflik. Menurut Carib dalam kajian teori struktural setidaknya ada sembilan indikator konflik itu dapat terjadi, empat diantaranya yaitu (1) Ada kepentingan, (2) ada dorongan, (3) kehidupan sosial yang terbagi, (4) sistem sosial cenderung berubah. (M. Jacky, 2015, hlm. 111).

Kedua, kajian umum perkawinan dalam kerangka hukum positif. Perkawinan dalam hukum nasional masuk pada bab hukum keluarga dan menjadi bagian yang tidak terpisahkan dari hukum privat khsusunya keperdataan. Secara umum regulasi materiil dalam masalah hukum keluarga terdiri dari beberapa proses dalam formulasi hukum positif termasuk mengkomodir nilai-nilai ajaran agama Islam bagi pemeluknya. Proses itu dapat penulis simpulkan ke dalam beberapa tahapan yaitu: saat hukum keluarga prakolonial Belanda, hukum di saat masa kolonial Belanda, hukum keluarga awal kemerdekaan, ketika Indonesia sesudah tahun 1950, lalu lahirnya UU RI No. 1 Tahun 1974 Tentang Perkawinan dan keberlakuan khusus bagi beragama Islam terdapat di KHI berdasar Inpres No. 1 Tahun 1991 yang hingga kini, keduanya masih tetap berlaku serta menjadi rujukan utamanya. (A. Kadir Muhammad, 2014).

Selain itu masih banyak aturan khusus tertulis lainnya yang mengatur permasalahan perkawinan untuk TNI, Polisi, PNS. Di dalam undang-undang RI 
nomor 1 Tahun 1974 Tentang perkawinan Pasal 1 yang dimaksud perkawinan secara definitif adalah ikatan lahir dan batin antara seorang pria dengan seorang wanita sebagai suami istri dengan tujuan membentuk keluarga (rumah tangga) yang bahagia dan kekal berdasarkan Ketuhanan Yang Maha Esa. Redaksi pasal memiliki poin penting, pertama, bahwa perkawinan itu dianggap legal jika dilakukan oleh pria dan wanita, maka perkawinan sejenis itu dilarang. Kedua, terdapat isyarat bahwa perkawinan di Indonesia pada dasarnya menganut paham monogami terbuka (monogami tak mutlak), memiliki keterkaitan penjelas pada pasal 3 UUP. Ketiga, membentuk keluarga yang bahagia, atau dalam istilah agama Islam ialah keluarga sakinah (ketenangan), mawadah (cinta), ar-rohmah (berkasih sayang), maka sejatinya tujuan perkawinan tersebut tidak sekedar masalah penghalalan hubungan biologis, dan keempat, bahwa perkawinan harus memiliki nilai sakralitas ketuhanan dan keagamaan. Perkawinan yang sah dalam pandangan hukum positif (Pasal 2 dan 3 UUP), apabila dilakukan sesuai hukum agamanya masin-masing dan wajib dicatatkan menurut peraturan perundang-undangan yang berlaku, tidak sirri. Selanjutnya untuk perkawinan orang beragama Islam berlaku khusus KHI yang sebagai "lex Specialis" dari UUP (lex generalis). Perkawinan dalam KHI pasal 2, memiliki arti akad yang sangat kuat atau miitsaaqan gholiidhan dalam rangka menaati Allah dan melaksanakannya dinilai sebagai ibadah. (Abdurrahman, 2004). Kompilasi Hukum Islam sebenarnya merupakan "fiqh" itu sendiri yang ditingkatkan menjadi level nasional untuk keberlakuannya. Tidak kurang dari 40 kitab yang dijadikan rujukan dalam membentuk KHI ini. (Abdurrahman, 2004).

Salah satu syarat perkawinan pada pasal 6 ayat 1 UU RI No. 1 Tahun 1974 adalah bahwa perkawinan harus atas persetujuan kedua calon mempelai. Begitu pula dengan KHI pasal 16 ayat 1, juga menegaskan perkawinan didasarkan atas persetujuan para calon mempelai. Seterusnya pasal 27 ayat 1 UUP menerangkan suami atau istri dapat mengajukan permohonan pembatalan perkawinan apabila perkawinan dilangsungkan di bawah ancaman yang melanggar hukum. Sejalan dengan ketentuan dalam KHI, pembatalan perkawinan dalam konteks pemaksaan landasan hukumnya terdapat pada pasal 71 poin (f) dan (a), termasuk jika seorang pria berpoligami namun tidak mengantongi izin dari PA, maka dapat dibatalkan. Kebebasan memilih pasangan hidup juga merupakan bagian dari unsur hak asasi 
manusia dan dijamin oleh negara melalui UU RI No. 39 Tahun 1999 Tentang HAM Paal 10 ayat 2. MUI ikut berpartisipasi dengan memperkuat aturan-aturan yang ditetapkan oleh negara sebagai wujud kepastian hukum dan bentuk perlindungan bagi warga negaranya, hal ini dituangkan dalam hasil Rapat Dewan Pimpinan Harian MUI tanggal 6 April 1996, ada dua poin dari enam poin hasil kesepatakan di pertemuan itu, yakni pada poin 1 dan 3 . Poin 1 dikatakan bahwa pernikahan dalam Islam merupakan hal sakral, luhur, dimaknai ibadah kepada Allah, mengikuti sunnah Rasulullah, dan dilaksanakan atas dasar keikhlasan, tanggung jawab, dan mengikuti ketentuan-ketentuan hukum yang harus diindahkan dan poin 3 kurang lebih sama dalam hal tunduk pada peraturan yang berlaku, disitu disebutkan UU RI No. 1 Tahun 1974 Tentang Perkawinan. (Himpunan Fatwa MUI, 2015).

Wujud perlindungan hukum lain terutama pencegahan kawin paksa pada anak merupakan tanggungjawab orangtua, diatur dalam pasal 26 ayat 1 poin (c) UU RI No. 35 Tahun 2014 perubahan atas UU RI No. 23 Tahun 22 Tentang Perlindungan Anak.

Ketiga, kajian umum perkawinan dalam fiqh. Kita biasa mengenal hukum Islam dengan istilah syariah (syariat/syarî'ah). Pada kenyataannya pula kita tidak membedakan antara istilah syariat dengan fiqh, dalam masalah fiqh terdapat pembahan-pembahasan yang di dalamnya mencakup permasalahan ikhtilaf (perbedaan pendapat). Kembali ke syariat, istilah syariat digunakan di dalam alQur'an dalam menunjuk suatu pengertian atau dalam pendeketan etimologi syariat adalah jalan menuju aliran air, pngertian lain syariat jalan yang terang dan nyata untuk mengantarkan manusia kepada keselamatan dan kesuksesan di dunia dan akhirat, dalil salah satunya pada al-Qur'an surat Asy-Syurâ ayat 13. (A. Rahman Dahlan, 2011).

Sedangkan menurut Nicolas $P$. Aghnides menyatakan bahwa syariat merupakan sesuatu yang tidak akan diketahui adanya kalau tidak ada wahyu Allah Swt. Bagi seorang muslim tidak akan dapat mengetahui sesuatu jika Allah tidak memberitahukan melalui wahyunya. (Abdul Djamali, 2002).

Dari kedua definisi di atas dapat kita simpulkan syariat diumpamakan aliran air, ialah karena syariat merupakan aturan Allah, secara keseluruhan untuk mengatur jalannya kehidupan alam semesta, termasuk manusia dan makhluk ciptaanNya, mencakup seluruh kehidupan sampai ke hal-hal terkecil. Aturan tersebut 
disampaikan melalui wahyu kepada nabi dan rasulnya. Sehingga aturan atau hukumhukum Allah Swt ini tidak hanya berbicara halal-haram, bagaimana tata cara ibadah saja, melainkan seluruh hubungan alam semesta dan bersifat kasuistik, contoh bagaimana bumi berputar, bagaimana malaikat menjalankan tugasnya, bagaimana hujan turun, dan lain-lain. Jadi "hukum" yang dimaksud juga meliputi hukum (tata cara) alam semesta ini bekerja dari mulai makrokosmos hingga mikrokosmos.

Berbeda dengan fiqh/fikih, memang fiqh merupakan bagian dari syariat itu sendiri, namun cakupan fiqh itu lebih sempit, sehingga istilah fiqh itu bukanlah syariat dalam makna umum atau luas. Jika diibaratkan bahwa syariat sebagai sebuah lingkaran besar, kemudian di dalam lingkaran tersebut terdapat lingkarang kecil lagi itulah posisi kedudukan fiqh. Fiqh secara etimologi menurut Ibnu asSubki, adalah "paham". Dengan demikian ketika seseorang mengatakan فَفَهَ artinya "saya paham", seseorang memberikan ilustrasi bahwa ia sudah mengerti (paham). (A. Rahman Dahlan, 2011).

Lebih mudahnya menurut penulis, fiqh adalah keterangan dari peraturanperaturan yang digali dari sumber utama hukum Islam yang kemudian direduksi secara sederhana dan digunakan untuk menjalankan amaliah praktis sehari-hari, contoh ruang lingkup fiqh yaitu tentang halal haram, boleh dan tidak, atau lebih spesifik misal bagaimana melakukan gerakan takbir dalam sholat, melaksanakan tata cara wudhu. Contoh dari hal-hal tersebut itulah masuk ranah fiqh. Fiqh sangat luas topik pembahasannya, biasanya terbagi dari bab per bab, seperti bab bersuci, bab sholat dan lain sebagainya.

Keterkaitan dengan topik kali ini adalah perkawinan yang mana masuk pada bab munakahat (pernikahan). Nikah secara bahasa berarti menggabungkan dan menyatukan serta saling memasuki. Beberapa perumpamaan dalam istilah arab diambil dari تَنَا كَحَت انلأ شُجَا رُ sebagian pohon menyatu dengan sebagian yang lain. Jika dilihat dari makna syar'i, nikah yaitu akad yang mengandung pembolehan antara suami dan istri untuk saling menikmati pasangannya dengan tata cara disyariatkan. (A. A. Mabruk Al-Hamidi,2016).

Dalil-dalil disyariatkannya menikah cukup banyak dalam al-Qur'an, beberapa diantaranya penulis merujuk pada buku kitab Fiqh Sunnah karya Sayyid Sabiq, yakni al-Qur'an surat ar-Ra'd ayat 38 , arRum ayat 21 , an-Nuur ayat 32 , dan anNahl ayat 72 , syariat menikah juga banyak 
Morality : Jurnal Ilmu Hukum

dijelaskan dalam hadist-hadist nabi Saw. (Sayid Sabiq, 2008).

Tentang syarat dan rukun menikah terdapat perbedaan pendapat tentang klasifikasi penetapan kategori yang masuk pada kelompok syarat dan rukun, begitu pula dalam regulasi yang berlaku di negara kita, misalkan dalam mazhab Syafi'i secara umum yakni rukun nikah terdiri dari (a) sighat, (b), calon suami, (c) calon istri, (d) dua orang saksi dan (e) ada wali, untuk saksi dan wali termasuk pula dalam persyaratan. (W. Zuhaili, 2010, hlm. 453.).

Sedangkan menurut Abdul Aziz Mabruk Al-Hamidi, titik perbedaannya ada pemisahan antara rukun dan syarat. Rukun menikah paling tidak menurutnya ada lima indikator, yaitu; (a) penentuan setiap pasangan dari suami dan sitri, kerinciannya dari shighat, identitas dan yang terkait di dalamnya, (b) Kerelaan dari masingmasing mempelai pengantin terhadap pasangannya, jika ditemukan adanya paksaan, maka pernikahannya tidak sah, (c) perwalian dalam pernikahan, (d) ada kesaksian dalam pernikahan, dan (e) tidak ada penghalang untuk kedua mempelai misal adanya sepersusuan, kandung (nasab). Mengenai rukun pernikahan terdiri dari para pihak pelaku akad, Ijab, dan Qabul. (A. A. Mabruk Al-Hamidi, 2016).

\section{Desember 2020, Volume 6 Nomor 2}

Pernikahan yang baik adalah pernikahan yang dilaksanakan berdasar pilihannya atas dasar tidak adanya paksaan, memang orang tua memiliki sedikit hak memilih atau mencarikan pasangan bagi anak perempuannya, hanya saja perlu ditekankan adalah konteks memilihkan tersebut manakala anak perempuannya "salah langkah" dalam memilih yaitu ketika ia mendapatan calon pria yang tidak baik (pemabuk dan sebagainya), baru disini wali dari perempuan memiliki peran untuk ikut campur. Fiqh munakahat mengatur kebebasan atau hak opsi seorang perempuan untuk memilih pasangannya hidupnya. Dasar hukumnya dalam alQur'an seperti dalam surat Al-Baqarah ayat 230 dan 232. Ayat di atas cukup sebagai penjelas bahwa dalam kaitannya seorang wanita memilih pasangan untuk pernikahannya, berangkat dari diri si wanitanya itu sendiri. Wanita diberikan kemerdekaan mutlak untuk menolak lakilaki yang ingin menjadi suaminya jika wanita yang bersangkutan tidak merasa cocok dan ini termasuk sunnah nabawiyyah serta tidak boleh ada paksaan dari wali yang akan menikahkannya. (M. Ustman Al-Khasyt, 2010).

Serta sunnah nabi Saw bersumber dari hadis riwayat Imam Bukhari dan 
Imam Muslim yang berbunyi: Dasar hukumnya berangkat dari hadis :

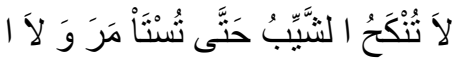

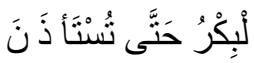

"Seorang janda tidak boleh dinikahkan hingga dimintai keputusan terlebih dahulu dan seorang gadis tidak boleh dinikahkan hingga dimintai izin terlebih dahulu."

Konteks penjelasan hadist dimaksud dapat kita lihat dari penjelasan Muhammad Rasyid Ridha, bahwa penolakan anak perempuan terhadap calon pria yang dianggap tidak cocok atau tidak disukai atas pilihan maupun paksaan orang tuanya, bukanlah suatu perbuatan dosa. sikap menolak paksaan perkawinan tersebut bukan masuk dalam bagian kewajiban berbakti kepada orangtua karena perbuatan memaksa dalam kondisi di atas terkait dengan perbuatan mencabut kemerdekaan dan kebebasan pribadi atau rumah tangga pada pribadi anak. (M. Qurasih Shihab, 2010).

Dalam sebuah hadist yang iriwayatkan Imam An-Nasa'i pernah ada seorang perempuan datang kepada nabi Saw, ihwal mengadukan peristiwa yang menimpa dirinya karena telah dijodohkan secara sepihak dan sewenang-wenang oleh ayahnya, kemudian rasul Saw mengembalikan permasalahan itu kepada wanita tersebut, secara tersirat seakan nabi Muhammad Saw memberikan opsi apakah rumah tangga itu dilanjutkan atau tidak dan perempuan itu tetap memilih melanjutkan, adapun kenapa ia mengadu ke rasulullah Saw adalah pesan dari representasi dirinya agar orang tua tidak dapat memaksakan kehendaknya sesuka hati dalam pernikahan.(M. Utsman AlKhasyt, 2010).

Posisi perempuan yang telah menjadi istri namun tidak senang terhadap suami menurut Imam Syaukani sudah dapat menjadi sebuah alasan untuk khulu' /proses gugat cerai istri. (Syafi'i Abdullah, n. y.),

Sedangkan Ibnu Mundzir berpendapat tidak boleh dan harus rasa tidak senang itu datang dari keduanya. (Sayid Sabiq, 2008).

Nur Hasan menceritakan, Rasulullah Saw, pun pernah mengalami dua kali penolakan lamaran sebelum beliau menikah dengan Siti Khadijah dan setelahnya. Perempuan yang menolak nabi Saw bernama Ummu Hani', ia adalah saudari dari Ali bin Abi Thalib. Penolakan pertama alasannya sangat mendasar, karena ia telah dipinang terlebih dahulu oleh orang lain dan yang kedua Ummu Hani' menolak dengan alasan khawatir akan menghambat gerak dakwah nabi Muhammad Saw karena telah memiliki 
anak yang banyak, namun peristiwa penolakan tersebut tidak pernah menjadikan nabi Muhammad Saw memaksakan kehendaknya, bahkan beliau membantu kehidupannya. (islami.co, 2018).

Dalam riwayat lainnya, ketika Rasul Saw memiliki anak perempuan dari ibunda Siti Khadijah yang bernama Zaenab binti Muhammad, singkatnya seorang pemuda bernama Abu Ash ingin meminang Zaenab ia mengutarakan kepada baginda Rasul Saw, setelah menerima niatannya itu Rasul Saw mengembalikan ke pihak Zaenab anaknya, walaupun dalam kisahnya tadi Rasuul Saw mengetahui bahwa putrinya Zaenab juga memiliki ketertarikan dengan pemuda bernama Abu Ash, hanya saja pelajarang yang dapat dipetik adalah Rasul Saw memberikan pelajaran untuk kita teladani bahwa Rasul memberikan kebebasan bagi anaknya untuk memilih (Badiatul Roziqin, 2019).

\section{PEMBAHASAN}

Perkawinan paksa ditinjau dari aspek Sosial, pernikahan sejatinya merupakan momentum sakral yang diharapkan tidak hanya sebatas selesainya pengucapan akad kemudian selesai, sehingga banyak dalam realitas sosialnya seakan-akan pernikahan menjadi sekedar ajang permainan, ajang melampiaskan kehalalan hawa nafsu syahwat saja. Pernikahan dengan cara memaksakan kehendak tidaklah pantas dan tidak membawa sebuah kebaikan, walaupun mungkin satu atau dua hal perkawinan yang terjadi dikarenakan paksaan berjalan dengan baik. Fenomena kawin paksa yang marak terjadi diberbagai derah seperti di Tasikmalaya, kabupaten Bekasi, bahkan di luar negeri seperti Ethiopia, merupakan bagian dari fenomena sosial. (M. Jacky, 2015), mengapa?, karena peristiwa perkawinan dengan paksaan terjadi secara berulang-ulang, hampir kondisi tersebut tidak pernah hilang pada setiap waktu yang berbeda. Kalau kemudian kawin paksa ini telah hilang dan tidak terjadi lagi maka bukan masuk pada kategori fenomena sosial hanya kasus saja.

Kejadian demi kejadian perkawinan dengan paksaan seakan-akan telah membudaya dan tertutup ruang dialog serta penafsiran, namun patut diketahui suatu kreasi manusia tersebut tidaklah selalu dapat dipandang baik, alasan kenapa kawin paksa menjadi seperti layaknya tradisi itu terjadi dengan interval yang terbilang sering sehingga menjadi melekat di cara hidup sebagian masyarakat. PANDANGAN Clyde, budaya juga menjadi salah satu barometer dari standarisasi "kelakuan" orang tersebut. (Jacobus Ranjabar, 2013). 
Kawin paksa tampaknya di wilayah tertentu menjadi semacam standarisasi penilaian, jika saja mungkin pihak perempuan telah pasti mendapat pasangan yang baik itu tidak mengapa, tetapi jika sebaliknya, maka akan menimbulkan masalah. Dengan adanya perkawinan dengan pola yang dipaksakan ini pranata budaya mencoba memberikan pandangan bahwa seorang telah pasti melakukan kebaikan dengan mencegah hal-hal buruk, namun kenyataan tidak selalu seindah apa yang didealkan. Perkawinan yang dilakukan atas dasar paksaan lebih banyak menimbulkan permasalahn sosial baru dan konflik. Contoh fenomena kawin paksa menjadi sebuah standarisasi penilaian, kita dapat jumpai salah satunya pada artikel penelitian tentang studi gender dan Islam karya Masthuriyah Sa'dan, termuat dalam jurnal Musawa di tahun 2015 dimana ia menyoroti fenomena kawin paksa yang terjadi di Madura, satu dari sekian temuannya bahwa terdapat faktor pengaruh pemahaman sempit terhadap produk kitab kuning produk masa lampau yang bias gender serta tak terlepas dari tradisi budaya patriakhi Arab, padahal menurutnya peristiwa seperti itu menjadi bagian yang melatarbelakangi terjadinya perceraian dan KDRT, walaupun tujuan awalnya adalah menghormati orang tua. Dalam proses perjodohannya tidak jarang pihak calom perempuan tidak mengenal bahkan tidak mengetahui calon mempelai prianya. (Masthuriyah Sa'dan, 2015).

Kita dapat simak, latar belakang terjadinya kawin paksa sangat beragam, ada yang didasari atas argumentasi keagamaan, seperti contoh kasus di atas, ada yang karena kurangnya pendidikan, dan mungkin lebih banyak atas dasar kesenjangan dari kesejahteraan sosial. Karena tumbuh kembang nilai suatu budaya dapat dipengaruhi faktor pemahaman agama, pendidikan dan kesejahteraan. (Jacobus Ranjabar, 2013).

Perkawinan paksa dapat terjadi berdasar doktrin agama yang sempit, peluang ini sangat mungkin muncul jika penyampaian doktri-doktrin agama disampaikan dengan sangat tekstual, bahkan terkadang tidak proporsional, contoh jika dilihat dari ajaran Islam, agama Islam banyak memiliki opsi dalam membina seseorang agar tidak terjerumus pergaulan bebas, ada opsi menikah, namun perlu diketahui pula kondisi seseorang untuk dapat melangsungkan pernikahan. Ulama membagi hukum pernikahan setidaknya menjadi empat kategori yaitu: pertama, wajib manakala ia yakin tak mampu menjaga kehormatannya walaupun sudah berpuasa, terlebih secara mental dan finansial sudah mampu. Kedua, pernikahan menjadi haram ketika orang yang hendak 
melaksanakannya khawatir menzhalimi atau membahayakan calon pasangannya, contoh seorang laki-laki memiliki penyakit kelamin, atau laki-laki yang yakin tidak mampu berbuat adil dalam kaitannya poligami. Ketiga, menikah menjadi makhruh disaat dalam kondisi mampu secara finansial tetapi ia berniat tidak menikah, dan keempat, menikah menjadi sunnah ketika ia tidak khawatir terjerumus pada yang haram seperti berbuat zina dan lainnya, hanya saja dalam pandangan umum mazhab Syafi'i hukumnya menjadi mubah/boleh. (Tim Ulin Nuha Ma'had 'Aly An-Nur, 2018).

Maka dalam pemahaman agama Islam yang luas masih ada bentuk pilihan lain selain perkawinan di usia dini atau perkawinan yang diaksanakan atas dasar paksaan, opsi tersebut seperti beragamnya anjuran untuk mengelola hawa nafsu, semuanya bersifat terkait satu sama lain dan tidak dapat dipisah-pisah. Kemudian faktor pengaruh pendidikan juga memiliki andil besar dalam cara pandang seseorang terhadap seuatu masalah, dengan keilmuan yang tepat seseorang tidak akan memaksakan kehendak pribadinya, menelusuri lebih jauh akibat dan dampak yang akan dirasakan dan terakhir adalah motif kurangnya kesejahteraan sosial terutama sisi kehidupan ekonomi, kehidupan dengan kondisi ekonomi rendah sering menjadi motif dasar terjadinya perkawinan paksa, pemikiran bahwa jika seorang anak gadis segera dinikahkan, maka segala permasalahan beban hidup satu persatu telah selesai, kehidupan keluarga menjadi lebih terjamin. Motif ini sulit sekali dimunculkan dengan verbal karena lebih sering tertutup dengan alasanalasan lain seperti beberapa poin sebelumnya, misal yang paling sering terwujud dalam perkataan jika seorang anak perempuan menikah dengan pilihan kakaknya atau ibunya (kerabat), pihaknya akan terbantu dengan dipinjami modal atau usaha. Pola-pola seperti jelas menampilkan motif ekonomi yang mendasari perkawinan paksa itu. Akan lebih jelas terlihat keterkaitannya dengan motif ekonomi ini dengan teori budaya Marx, ia berpendapat secara garis besar bahwa budaya-budaya demikian itu semua memiliki motif kapitalistik, adanya pandangan kesenang-kesenangan dikemudian hari, akan merasakan kenikmatan hidup yang tidak ada beban, ketentraman, kesemuanya adalah kesadaran palsu. (Ben Agger, 2017). Ketika disambungkan benang merahnya dengan peristiwa fenomena sosial kawin paksa tentu terlihat menjadi salah satu jalan pintas untuk mendapatkan imingiming di atas yang nyata-nyata belum pasti. 
Kebebasan wanita memilih calon suami dalam hukum positif dan fiqh. Kebebasan atau dalam kosakata bahasa inggris dikenal dengan "freedom". (J. M. Cholis \& Hassan Shadily, 2003).

Kebebasan, suatu kata yang begitu sangat bernilai dan berharga. Perempuan seakan selalu diposisi yang tersudutkan jika dihadapkan pada kebiasaan tertentu dan menjadi semacam personifikasi dari posisi inferior yang mengharuskan ia tunduk dan patuh tanpa terlepas kontesk kehidupannya, dalam pembahasan ini tentunya, hilangnya hak memilih atau kebebasan seorang perempuan ketika harus memilih calon suaminya. Peristiwa seperti ini tidak jarang berujung pada perawinan dengan paksaan. Padahal sangat bertentangan dengan semangat hukum dan juga bertentangan dengan apa yang di amanahkan dalam Islam melalui fiqh, kita akan mencoba menjabarkan dasar-dasar hukum positif dan fiqh bahwa seorang wanita memiliki hak dalam menentukan calon suaminya.

Pertama, dalam sudut pandang hukum positif dasar sebuah perkawinan yang sah selain dari pada kesamaan agama adalah pernikahan itu didasari tanpa adanya paksaan, pasal 6 ayat 1 Undangundang Republik Indonesia nomor 1 Tahun 1974 Tentang Perkawinan, menjelaskan bahwa sebuah perkawinan dilaksanakan atas persetujuan dua belah pihak, redaksi "..persetujuan dua belah pihak," menunjukkan corak UUP seimbang antara wanita dan laki-laki, begitu pula di dalam pasal 16 ayat 1 Kompilasi Hukum Islam, pernikahan harus didasari kesepatakan dua calon mempelai. Ketika tidak ada kerelaan salah satu pihak maka perkawinan tidak dapat dilaksanakan. Akibat hukum yang ditimbulkan jika ditemukan adanya unsur pemaksaan pernikahan, unddang-undang perkawinan tidak secara tegas mengatur. Pada UUP tidak terjadinya suatu perkawinan beberapa diantaranya adalah melalui pembatalan perkawinan atau perceraian. Kawin paksa hanya dapat dibatalkan jika memenuhi unsur pada pasal 27 ayat 1 UU RI No. 1 Tahun 1974 tentang Perkawinan yakni jika ada unsur "ancaman yang melanggar hukum," bisa berupa atas dasar peristiwa pemaksaan perkawinan itu, sedangkan untuk perceraian salah satunya diperkuat oleh PP No. 9 Tahun 1975 diantaranya; (a) salah satu pihak berbuat zina atau menjadi pemabok, pemadat, penjudi, dan sebagainya yang sukar untuk disembuhkan; (b) salah satu pihak meninggalkan yang lian selama dua tahun berturut-turut tanpa izin pihak lain dan tanpa alasan yang sah, atau karena hal lain di luar kemampuannya; (c) salah satu 
Morality : Jurnal Ilmu Hukum

pihak mendapat hukuman penjara lima tahun atau hukuman yang berat setelah perkawinan berlangsung; (d) salah satu pihak melakukan kekejaman atau penganiyaan berat yang membahayakan pihak yang lain; (e) salah satu pihak mendapat cacat badan atau penyakit dengan akibat tidak dapat menjalankan kewajibannya sebagai suami atau istri; (f) antara suami dan istri terus menerus terjadi perselisihan dan pertengkaran dan tidak ada harapan akan hidup rukun lagi dalam rumah tangga. (A. Kadir Muhammad, 2014).

Namun, jika ia adalah orang yang beragama Islam dan terjadi pemaksaan dalam proses pernikahannya menurut Kompilasi Hukum Islam (KHI) pasal 71 poin (f), pernikahannya itu dapat dibatalkan. (Abdurrahman, 2004).

Jaminan kebebasan perempuan untuk memilih pasangan hidupnya diperkuat dengan pasal 10 ayat 2 Undangundang Republik Indonesia Nomor 39 Tahun 1999 Tentang HAM, yang dipertegas dengan adanya klausul "kehendak bebas" calon suami dan calon istri yang bersangkutan. Tidak lupa terdapat anjuran fatwa MUI tanggal 6 April 1996 poin (1), bahwa perkawinan itu hendaknya ada unsur keikhlasan. (Himpunan Fatwa MUI, 2015).

\section{Desember 2020, Volume 6 Nomor 2}

Kedua, perkawinan atas dasar paksaan bertentangan dengan sunnah nabi Muhammad Saw. Sebelum melanjutkan dalil-dalil yang rinci tentang adanya hakhak wanita dalam memilih pasangannya, perlu dilihat kembali satu peristiwa dimana Rasulullah Saw, pernah ditolak lamarannya sebanyak dua kali oleh Ummu Hanni dan nabi Muhammad Saw tidak pernah sama sekali melakukan tindakan pemaksaan atau tindakan-tindakan lain yang sifatnya menekan pihak perempuan, diluar dugaan beliau senantiasa menolong wanita tersebut tanpa harus memaksakan kehendak dengan menjadikannya istri. (islam.co, 2018).

Nabi Muhammad Saw merupakan sebaik-baiknya manusia, maka segala tindak tanduk perilaku kita idealnya mencontoh teladan sosok beliau. Wanita ditempatkan secara istimewa dalam Islam, tuntunan nabi Saw dengan sangat jelas memberikan pesan bahwa adalah tidak boleh suatu perkawinan pelaksanaanya dipaksakan khususnya disaat yang dipaksakan itu adalah wanita, hal yang diterapkan pula oleh beliau (Saw) ketika mendengar pendapat anaknya dari hasil pernikahan dengan ibunda Siti Khadijah yang bernama Zaenab saat akan dipinang oleh seorang pemuda Abu Ash. (Baidatul Roziqin, 2019). 
Bagaimana kemudian satu riwayat yang bersumber dari Imam Ahmad, Imam An-Nasai, dan Ibnu Majah, menceritakan seorang perempuan mengadukan kepada Rasulullah Saw perihal pernikahan hasil paksaan ayahnya, disitu nabi Saw memberikan semacam pilihan apakah wanita itu meneruskan rumah tangganya atau tidak. (M. Ustman Al-Khayst, 2010).

Dalam hadist lain yang menunjukkan kebolehan (wewenang) wanita untuk memilih pendamping hidupnya yaitu satu hadist yang diriwayatkan Imam Bukhari dan Imam Muslim, dimana secara garis besar seorang janda jika ingin dinikahi harus ada izin dari janda tersebut, begitu pula dengan seorang perempuan (gadis) tentu harus ada izin dari dirinya sendiri terlebih dahulu. (M. Ustman Al-Khasyt, 2010).

Pertanyaan paling mendasar seterusnya, apakah seorang gadis berdosa ketika menolak perjodohan jika ia tidak merasa cocok, nyaman atau tidak menyukainya?, menurut Syeikh Muhammad Rasyid Ridho, tidaklah berdosa, karena sifat perjodohan dengan cara dipaksakan, merupakan tindakan yang akan merenggut kemerdekaan seseorang dalam hidupnya. (M. Quraish Shihab, 2010).

Walaupun demikian patut digaris bawahi penolakan perjodohan paksa tersebut tidak boleh menggunakan caracara yang dilarang hukum positif kita, juga tidak melanggar syari'at seperti membentak, kontak fisik, dan cara-cara reaktif sejenisnya, harus disampaikan dengan santun, adab dan bil hikmah. Peran wali nasab atau orang tua menurut Muhammad Ustman Al-Khasyt, ada dalam konteks kondisi yang secara jelas atau dapat dilihat dengan pasti dimana calon yang dipilih oleh anak perempuannya berperilaku tidak benar menurut syari'at dan hukum, seperti tertangkap tangan saat ia seorang mabuk-mabukan, penjudi, serta segala bentuk aktifitas yang jelas-jelas dilarang agama.

Sedikit berbeda dari hukum nasional, jika ditinjau dari UUP, suatu peristiwa perkawinan paksa akan dilihat dulu konteksnya, apakah itu dengan ancaman yang melanggar hukum atau tidak, jika iya perkawinan itu dapat dibatalkan, jika tidak terbukti maka tidak dapat dibatalkan dan kawin paksa tidak masuk pada kategori alasan gugatan perceraian, sedangkan di Kompilasi Hukum Islam, kawin yang dipaksakan dapat menjadi alasan pembatalan perkawinan.

Di saat kondisi telah terjadinya pernikahan itu, dalam fiqh walau tidak secara tegas menyebutkan atas argumen kawin paksa suatu perkawinan dapat 
dibatalkan atau gugatan cerai, namun merujuk dari salah satu pendapat berdasar hadist riwayat Imam Bukhari, An-Nasai dan Ibnu Abbas, cukup dengan alasan tidak senang dapat menjadi dasar dilakukannya gugatan cerai (khulu') oleh istri kepada suami dengan membayar sejumlah uang ganti rugi seperti yang disampaikan Imam Syaukani. (Sayid Sabiq, 2008).

Maka jelas sudah dari segi hukum positif dan fiqh, wanita memiliki hak dan kebebasan untuk memilih atau menentukan pasangan hidupnya untuk dijadikan suami dan sejatinya kedepan tidak ada lagi peristiwa-peristiwa sebuah pernikahan dilakukan secara paksa.

Mengutip Nazarudin Umar dalam buku Ketika Fikih Membela Perempuan, beliau berpendapat dalam menyelesaikan permasalahan keadilan seksual, sebaiknya harus berani setiap dari kita untuk mempertanyakan keabsahan refrensi yang dijadikan dasar pijakan. (Nazarudin Umar, 2014).

\section{KESIMPULAN}

Kawin paksa merupakan bagian dari fenomena sosial, karena peristiwa ini terjadi berulang-ulang dimanapun baik itu di perkotaan maupun di pedesaan maupun di luar negeri. Kawin paksa seakan telah menjadi suatu kreasi (budaya) saat dilihat dari sudut pandang baik dan buruk, walaupun lebih tepatnya adalah sebuah tradisi atau hal yang dilakukan secara turun menurun. Dari kacamata budaya faktor kawin paksa bisa terjadi karena nilai pendidikan yang rendah, paham keagamaan yang sempit dan motif kesejahteraan. Poin pokok motif ekonomi erat pula dalam teori budaya Marx yang mengatakan bahwa budaya memiliki dimensi kapitalistik dengan iming -iming kebahagian, kesejahteraan dan lain sebainya tetapi menurutnya itu semua adalah semu.

Perkawinan dengan sebab adanya paksaan tidak sejalan dengan hukum yang berlaku di negara kita. Hak wanita untuk menentukan pilihan calon pendamping hidupnya terbuka dan dijamin oleh peraturan perundang-undangan, mulai dari Undang-undang RI Nomor 1 Tahun 1974 Tentang Perkawinan pasal 6 ayat 1 dan pasal 27 ayat 1, Kompilasi Hukum Islam pasal 71 poin (f), dan Undang-undang RI nomor 39 Tahun 1999 Tentang HAM pasal 10 ayat 2, diperkuat dengan anjuran hasil rapat harian MUI Pusat tanggal 6 April 1996 butir ke (1), bahwa suatu pernikahan itu dilaksanakan atas dasar keikhlasan. Pada Undang-undang perkawinan tersebut hak untuk pembatalan perkawinan dapat dilakukan jika ada unsur ancaman melawan yang melanggar hukum 
dan pernikahan yang sah adalah atas persetujuan kedua belah pihak, namun unsur pemaksaan dalam undang-undang in tidak masuk dalam kategori syarat diperbolehkannya perceraian. Sejalan dengan itu dalam KHI pernikahan diwajibkan adanya kerelaan dari kedua calon mempelai, ketika tidak tercapai dalam rumusan KHI maka perkawinan dapat dibatalkan. Dalam fiqh secara tegas menyatakan bahwa sorang wanita memiliki hak memilih calon suaminya, karena izin atas diri wanita tersebut adalah dirinya, dalam redaksi hadis menerangkan baik itu untuk janda maupun gadis. Hal ini diperkuat lagi dari riwayat yang menceritakan nabi Muhammad Saw mendapat pengaduan dari seorang perempuan yang telah dijodohkan oleh ayahnya dan nabi Saw memberikan pilihan untuk melanjutkan atau tidak melanjutkan rumah tangganya itu walau pihak perempuan lalu tetap meneruskan rumah tangganya. Riwayat nabi Muhammad Saw telah memberikan pelajaran berharga agar seorang laki-laki untuk tidak memaksakan kehendak kepada gadis pilihannya, ini digambarkan manakala Rasulullah Saw ditolak lamarannya dua kali oleh Ummu Hanni tepatnya sebelum pernikahan beliau dengan Siti Khadijah dan setelahnya. Rasul Saw juga menerapkan opsi hak untuk memilih itu kepada putrinya yang bernama Zaenab.

Bagi wanita yang dipaksakan menikah dan telah dalam kondisi menikah maka fiqh memberikan keterangan pihak istri dapat mengajukan khulu' (gugatan cerai) dengan membayar sejumlah uang pengganti bagi pihak suami yang digugat.

\section{DAFTAR PUSTAKA}

Abdurrahman. (2004). Kompilasi Hukum Islam Di Indonesia. Jakarta: Akademika Presindo.

Abdullah, S. (n. y.). Seputar Fiqih Wanita Lengkap. Surabaya: Arkola.

Achdami, M. (2018, May 3). Retrieved June 24, 2019, from http://harnas.co/2018/05/03/60persen-anak-di-kabupaten-bekasidipaksa-nikah-muda.

Agger, B. (2017). Teori Sosial Kritis, Kritik, Penerapan dan Implikasinya. Bantul: Kreasi Wacana.

Al-Hamidi, A. A. M. et. al. (2016). Fikih Muyassar Panduan Praktis Fikih dan Hukum Islam Lengkap Berdasarkan Al-Qur'an dan AsSunnah. Jakarta: Darul Haq.

Al-Barry, M. D. (1994). Kamus Modern Bahasa Indonesia. Yogyakarta: Arkola.

Armia, M. I. (2011, April 1). Retrieved June 26, 2019, from http://etheses.uinmalang.ac.id/2530/. 
Creswell, J. W. (2014). Research Design Pendekatan Metode Kualitatif, Kuantitatif dan Campuran. Yogyakarta: Pustaka Pelajar.

Dahlan, A. R. (2011). Ushul Fiqh. Jakarta: Amzah.

Djamali, A. (2002). Hukum Islam Berdasarkan Ketentuan Kurikulum Konsorsium Ilmu Hukum. Bandung: Mandar Maju.

Himpunan Fatwa MUI Sejak 1975 Edisi Terbaru. (2015). Jakarta: Emir Cakrawala.

Hasan, N. ( 2018, November 23). Retrieved July 14, 2019, from https://islami.co/ummu-haniperempuan-yang-menolak-cintapertama-rasulullah-saw/.

Irawan, I.B. (2014). Teori-Teori Sosial Dalam Tiga Paradigma Fakta Sosial, Definisi Sosial, \& Perilaku Sosial. Jakarta: Kencana Ilmu.

Jacky, M. (2015). Sosiologi, Konsep, Teori, dan Metode. Surbaya: Mitra Wacana Media.

Kurniawan, A. (2016). Kawin Paksa Dalam Pandangan Kiai krapyak. Jurnal Al-Ahkam UIN Sunan Kalijaga, 9 (1), 101-124.

Lahitani, S. (2017, May 23). Retrieved June 24, 2019, from https://www.liputan6.com/citizen6/re $\mathrm{ad} / 2961405 /$ tragis-pengakuan-gadisyang-dipaksa-menikah-pada-usia-7tahun.

Muhammad, A. K. (2014). Hukum Perdata Indonesia. Bandung: Citra Aditya Bhakti.
Mamudji, S. \& Soekanto, S. (2007). Penelitian Hukum Normatif Suatu Tinjauan Singkat. Jakarta: Rajawali Press.

Mahfudin, A. \& Musyawaroh, S. (2019). Dampak Kawin Paksa Terhadap Keharmonisan Keluarga. Jurnal Hukum Keluarga Islam Universitas Pesantren Tinggi Darul Ulum Jombang Indonesia, 4 (1), April 2019, 776-93.

Jhon, M. J. \& Shadily, H. (2003). Kamus Inggris Indonesia. Jakarta: Gramedia.

Ranjabar, J. (2013). Sistem Sosial Budaya Indonesia Suatu Pengantar. Bandung: Alfabeta.

Roziqin, B. (2019). The Golden Stories Of Khadijah. Yogyakarta: Semesta Hikmah.

Rancangan Undang-Undang Republik Indonesia Tentang Penghapusan Kekerasan Seksual. (2017, February 1). Retrieved July, 07, 2020, from http://www.dpr.go.id/doksileg/proses 2/RJ2-20170201-043128-3029.pdf.

Rahardian, D. (2019, February 22 ). Retrieved June, 26, 2020, from https://news.detik.com/berita-jawabarat/d-4439142/kpai-tasikmalayasayangkan-perjodohan-paksa-hilda

Sabiq, S. (2008). Fiqih sunnah Jilid 2. Jakarta: Pena Publisher.

Sabiq, S. (2008). Fiqih Sunnah Jilid 3. Jakarta: Pena Publisher.

Sa'dan, Masthuriyah. (2015). Menakar Tradisi Kawin Paksa di Madura dengan Barometer HAM. Jurnal Studi Gender dan Islam Musawa, 14 (2), Juli 2015, 143-155. 
Shihab, M. Q. (2010). M. Quraish Shihab Menjawab 101 Soal Perempuan Yang Patut Anda Ketahui. Jakarta: Lentera Hati.

Soekanto, S. (2006). Pengantar Penelitian Hukum. Jakarta: UI-Press.

Tim Ulin Nuha Ma'had Aly An-Nur. (2018). Fiqih Munakahat Kajian Praktis Fiqih Pra-Pasca Nikah Merajut Sakinah dalam Sentuhan Islam. Sukoharjo: Kiswah Media.

Ustman, M. A. (2010). Fiqih Wanita Empat Mazhab Mengupas Tuntas Berbagai Permasalahan Seputar Hukum Fiqih Muslimah Dalam Kehidupan Sehari-hari. Bandung: Khazanah Intelektual.

Umar, N. (2014). Ketika Fikih Membela Perempuan. Jakarta: Quanta.

Undang-undang Republik Indonesia Nomor 39 Tahun 1999 Tentang Hak Asasi Manusia.

Undang-undang Republik Indonesia Nomor 1 Tahun 1974 Tentang Perkawinan.

Undang-undang Republik Indonesia Nomor 35 Tahun 2014 Tentang Perubahan Atas Undang-undang Republik Indonesia Nomor 23 Tahun 2002 Tentang Perlindungan Anak.

Zuhaili, W. (2010). Fiqih Imam Syafi'i Mengupas Masalah Fiqhiyah Berdasarkan Al-Qur'an dan Hadist. Jakarta: Almahira. 